\title{
STUDY VARIETY INDEXES OF VARIETY KIBRAY OF KASHKAR BEDA (MELILOTUS ALBUS)
}

\author{
Fozilbek Nurullaevich Toreev \\ Associate Professor, Department of Genetics, Plant Breeding and Seed Production of Agricultural Crops, \\ Tashkent State Agrarian University, University str., 3, Tashkent-100140, Uzbekistan
}

\begin{abstract}
Djabbarkhon Djamalkhanovich Akhmedov
Associate Professor, Department of Genetics, Plant Breeding and Seed Production of Agricultural Crops, Tashkent State Agrarian University, University str., 3, Tashkent-100140, Uzbekistan
\end{abstract}

\section{Muzaffar Matyakubovich Yakubov}

Doctoral Candidate of the Department of Genetics, Plant Breeding and Seed Production of Agricultural Crops, Tashkent State Agrarian University, University str., 3, Tashkent-100140, Uzbekistan

\author{
Gavkhar Abdakhatovna Tilovova \\ Teacher of Languages Department, Tashkent State Agrarian University, \\ University str., 3, Tashkent-100140, Uzbekistan
}

\begin{abstract}
Nasiba Umarovna Mavlanova
Assistent of the Department of Genetics, Plant Breeding and Seed Production of Agricultural Crops,

Tashkent State Agrarian University, University str., 3, Tashkent-100140, Uzbekistan
\end{abstract}

Article DOI: https://doi.org/10.36713/epra4098

\begin{abstract}
Enhancing of soil fertility is required for getting high yields from cotton plant, cereals and other crops in Uzbekistan. It may be achieved through implementation of crop rotation, properly introduction of rotation and by the planting of kashkar beda, alfalfa and other bean bearing crops.

Planting of Kibray variety of Kashkar beda in strongly salted areas and may be produced high yields than ordinary blue alfalfa. It's an average green mass yield accounts for 4.0-4.5 tons per hectare, $1 \mathrm{~kg}$ green mass contains 17 $25 \mathrm{~g}$ protein and 0,16-0,20 food units what is a nutritious food for agricultural animals. Beside this, due to its root nitrogen-fixing capability. It may be taken durable high yields from other crops in its planted area. Keywords: Kashkar beda (local diversity of alfalfa), blue alfalfa, green stem, salinization, productivity, protein, food unit, forage, farmstead, variety, seed production, elite, primary seed production, nutritional crops, green mass, morphologic traits, germination, variety grade, nursery, individual selection, phonologic monitoring, Kibray variety, variety of Tashkent-2009.
\end{abstract}

KEYWORDS: Kashkar beda, Melilotus albus, variety, green mass, morphologic traits, germination. 


\section{INTRODUCTION}

A lot of farms in the irrigated lands of the republic, in particular the farms with the direction of animal husbandry have been established at the carrying out the reforms in agriculture. The lands were allocated to cultivation of food and forage crops for livestock farms and consolidation their source of supply. It is obvious, that it is a difficult course to famers obtain in high yield and sustain their forage storehouses on salinized lands [4]. According to the data of MA, about $49 \%$ of irrigated lands of Uzbekistan have been salinized at the different extents. The lands subjected at the different extent much salinization in the following regions and the salinization percentage of irrigating lands correspondingly: Karakalpakistan republic 77\%, Khorezm region 95\%, Bukhora region 87\%, Jizzakh region $79 \%$, Navoy region $87 \%$ ans Syrdaria region $98 \%$.

Every year about 25-40 tons of nutritious forages are produced from the lands of animal husbandries. Naturally, several ten kilograms of macro and microelements in their texture take away from soil. Nitrogen, phosphorus and potash elements are partially returned as the quality of mineral fertilizers, but they will not fully be assimilated by the plants and one part will left in the soil. On the account of the decreasing of soil fertility year by year, the productivity of forage and other crops is also reduced gradually.

At the same time, increasing the soil fertility is required in order getting high yields from cotton plant, cereals and other crops in Uzbekistan. This can be achieved by the way of properly introduction of crop rotation and planting alfalfa and other bean yielding crops [3].

\section{MATERIALS AND METHODS}

Method of experiment - GOST 19453-80 "Standard of elite seeds" requirements on the preparation method of alfalfa elite seeds was used as the method of experimental researches. Research object Kibray variety of Kashkar beda, Tashkent - 2009 variety of blue alfalfa.

\section{RESULTS AND DISCUSSION}

The alfalfa is a source to the bumper crop which has almost of all vitamins in its structure necessary to agricultural animals, it considers as the main nutrition for livestock and it enhances the land texture in the rotation with increase the productivity of crops after itself. The alfalfa ranks top than all bean bearing grasses on the amount of protein substance in the structure of green mass which is necessary to the livestock [1]. And also, the importance of alfalfa is great owing to its agro technician and melioration features, it is a good sequenced crop to the most crops, so that for three years after planting of alfalfa, at the adequately conserved seedlings the soil enriches with numerous root residues and accumulated around $600-900 \mathrm{~kg}$ per hectare of absorbed nitrogen from air, it enhances soil texture (structure), water, physical and chemical features, it decreases the land salinization, disease infection of plants, so, it re-establishes the land's fertility and rises the productivity of crops in particular the cotton plant. With artificial way in the soil to accumulate $600-900 \mathrm{~kg}$ nitrogen per hectare needs apply of 3.8-4.1 tons of ammonium sulfate.

Alfalfa accumulates for three years about 600-900 $\mathrm{kg}$ nitrogen absorbed from air by means of tuber bacteria in the roots, but Kashkar alfalfa has an ability of accumulating such amount of nitrogen in two years. With this, Kashkar beda is able to give the green mass and hay in two years at the condition all of agro practices have been fulfilled in time than common alfalfa could give yields for three years. The superiority of Kibray variety of Kashkar beda is its high productivity in the strongly and moderately lands than any common alfalfa varieties. If the required agro practices for this variety are carried out in time and at good quality its green mass productivity reaches up to $4,0-4,5$ tons. $17-25 \mathrm{~g}$ of protein and $0,16-0,20$ nutritious units available in one kilogram of green mass [2]. This variety's high potential in the productivity in the same field condition, the same expands and agro practices, has been identified in the experiments than other common alfalfa varieties. Taking into account of these, the elite seeds preparation of "Kibray" variety of Kashkar beda by the arranging of its primary seed production is considered as the important goal [5].

Studing of variety grades in the seed production of agricultural crops is guessed one of the important goals. The results of the first cutting at the analysis of indexes of 100 plants after first and second cuttings of Kibray variety of Kashkar beda in the nursery of variety identity protecting enlightened the following performances. On the color of flower of Kashkar beda, 1 plant was not similar to the variety (Table 1).

According to the analysis of general state on the traits, one unit out of 100 plants of Kibray variety of Kashkar beda has been determined as the non-uniform (the color of flower was non-typical, that was yellow) and this plant was discarded. So, this shows that the purity index of the variety of Kibray is equal to 99 percent.

The following states were identified per first and second cuttings on the study of 100 plants for variety grade of Tashkent-2009 of blue alfalfa planted in its variety purity maintaining nursery: 1 plant on the leaf structure and another 1 is not similar to the variety on the umbel structure and the variety grade index of this variety has made up 98 percent (Table 1). 


\section{EPRA International Journal of Research and Development (IJRD)}

Volume: 5 | Issue: 3 | March 2020

- Peer Reviewed Journal

Table 1

Variety grade indexes of varieties Kibray of Kashkar beda and Tashkent-2009 of common alfalfa

\begin{tabular}{|c|c|c|c|c|c|c|}
\hline \multirow{2}{*}{$\begin{array}{c}\text { Name of plant } \\
\text { and variety }\end{array}$} & $\begin{array}{c}\text { Number of } \\
\text { studied } \\
\text { plants, unit. }\end{array}$ & $\begin{array}{c}\text { Color of } \\
\text { flower }\end{array}$ & $\begin{array}{c}\text { Structure } \\
\text { of leaf. }\end{array}$ & $\begin{array}{c}\text { Structure of } \\
\text { umbel }\end{array}$ & Totally & $\begin{array}{c}\text { Variety } \\
\text { grade, in } \\
\text { percent }\end{array}$ \\
\cline { 3 - 7 } $\begin{array}{c}\text { Kibray of Kashkar } \\
\text { beda }\end{array}$ & 100 & 1 & - & - & 1 & 99 \\
\hline $\begin{array}{c}\text { Tashkent-2009 of } \\
\text { alfalfa }\end{array}$ & 100 & - & 1 & 1 & 2 & 98 \\
\hline
\end{tabular}

The below presented states were discovered on the analysis of 100 plants' characteristics at the second cutting results in the variety maintaining nursery of Kibray variety of Kashkar beda: on the one plant was

\section{Table 2}

Variety grade indexes of Kibray variety of Kashkar beda and Tashkent-2009 variety of common alfalfa

\begin{tabular}{|c|c|c|c|c|c|c|}
\hline \multirow[t]{2}{*}{$\begin{array}{l}\text { Names of plant and } \\
\text { variety }\end{array}$} & \multirow{2}{*}{$\begin{array}{l}\text { Number of } \\
\text { studied } \\
\text { plants, unit. }\end{array}$} & \multicolumn{4}{|c|}{$\begin{array}{l}\text { Number of non-uniform (on the traits) plants, } \\
\text { unit. }\end{array}$} & \multirow{2}{*}{$\begin{array}{c}\text { Variety } \\
\text { grade, in } \\
\text { percent }\end{array}$} \\
\hline & & $\begin{array}{l}\text { Color of } \\
\text { flower }\end{array}$ & $\begin{array}{c}\text { Structure } \\
\text { of leaf }\end{array}$ & $\begin{array}{c}\text { Structure of } \\
\text { umbel }\end{array}$ & Totally & \\
\hline Kibray of Kashkar beda & 100 & & 1 & - & 1 & 99 \\
\hline Alfalfa Tashkent -2009 & 100 & - & - & 2 & 2 & 98 \\
\hline
\end{tabular}

The below listed states were discovered in the analysis of 100 plants' characteristics of Tashkent variety of blue alfalfa: 2 plants were non-typical to the variety on the structure of umbel in the observation (Table 2).

2 plants out of studied 100 plants of variety Tashkent-2009 of blue alfalfa in the analysis of general state on the above-mentioned traits were non-typical and so, it showed that the variety grade of Tashkent2009 of blue alfalfa is consisted 98 per cent. The approbation works in the seed stock plantations have been implemented by the participation S.Madaliev chairmen of farm "Gafur obod iftikhor", T.Allamberghanov - head of the department of "Service center at the agro-industry complex", F.Toreev manager of the project of I-QKH-2017-5-13 and scientific staff M.Yakubov and N.Mavlonova.

The weights of 1000 seeds of Kibray variety of Kashkar beda and Tashkent-2009 of blue alfalfa were analyzed. At this, per 3 samples have been separated from seeds of the varieties. The weight of first sampled Kibray variety of Kashkar beda equal to 2,51 g., the second sample $-2,44$ and the third $-2,54 \mathrm{~g}$. The mean index per three sample has made up 2,5 g.

\section{CONCLUSION}

Kashkar beda is a highly resistant plant to drought and salinity than alfalfa. Kashkar beda has the possibility to accumulate nitrogen into the soil deposit, green mass, hay and seed crop in two years than common alfalfa in three years. It was determined that the variety purity of Kibray variety of Kashkar beda is observed its non-typicality to the variety and so, the variety's variety grade index has made up 99 percent (Table 2). 